\title{
ENDOMETRIAL mRNA EXPRESSION OF PROSTAGLANDIN SYNTHASE ENZYMES PTGS 2, PTGFS AND mPTGES 1 IN REPEAT-BREEDING COWS WITH CYTOLOGICALLY DETERMINED ENDOMETRITIS
}

\author{
Tomasz JANOWSKI ${ }^{1 *}$, Wojciech BARAŃSKI ${ }^{1}$, Karolina LUKASIK $^{2}$, Dariusz SKARŻYŃSKI ${ }^{2}$, \\ Sławomir ZDUŃCZYK ${ }^{1}$ and Katarzyna MALINOWSKA ${ }^{1}$ \\ ${ }^{1}$ Department of Animal Reproduction with Clinic, University of Warmia and Mazury, \\ Oczapowskiego 14, 10-719 Olsztyn, Poland; ${ }^{2}$ Department of Reproductive Immunology \\ and Pathology, Institute of Animal Reproduction and Food Research of the Polish \\ Academy of Science, Olsztyn, Poland
}

(Received 13 June 2016; accepted 2 November 2016)

Little is known about the inflammatory response of the endometrium in repeat-breeding cows with subclinical endometritis (SE). The objective of this study was to evaluate the mRNA expression of prostaglandin-endoperoxide synthase 2 (PTGS 2), prostaglandin $\mathrm{F} 2_{\alpha}$ synthase (PTGFS) and prostaglandin $\mathrm{E} 2 \mathrm{mi}-$ crosomal synthase 1 ( $m P T G E S 1$ ) in the endometrium of repeat-breeding cows with and without SE. SE was diagnosed cytologically using the cytobrush method, with the threshold being set at $5 \%$ polymorphonuclear neutrophils. Biopsy samples were obtained from the endometrium of repeat-breeding cows with SE $(n=10)$ and without SE $(n=10)$. The mRNA expression of the synthases was evaluated using qRT-PCR. Significantly higher $(\mathrm{P}<0.05)$ expression of the PTGS 2 gene was detected in the repeat breeders with SE, whereas there was no significant difference in the expression of PTGFS and mPTGES 1 mRNAs between repeatbreeding cows with SE and those without it $(\mathrm{P}>0.05)$. Our study confirms that increased endometrial expression of the PTGS 2 gene is involved in the inflammatory response in repeat breeders.

Key words: Cows, repeat breeding, PTGS 2, PTGFS, mPTGES 1

Repeat breeding is one of the major problems in dairy cows (Båge et al., 2002; Gustafsson and Emanuelson, 2002; Yusuf et al., 2010). Repeat-breeding cows are defined as cows with three or more artificial inseminations without conception in the absence of any diseases (Gustafsson and Emanuelson, 2002). A high prevalence of subclinical endometritis in unsuccessfully inseminated cows, ranging from $12 \%$ to $53 \%$, has been reported (Salasel et al., 2010; Janowski et al., 2013; Pothmann et al., 2015).

*Corresponding author; E-mail: jantom@uwm.edu.pl; Phone: 0048 (89) 523-3896; Fax: 0048 (89) 523-3440 
Subclinical endometritis (SE) is defined as a slight inflammation of the endometrium without clinical signs of endometritis, which significantly reduces fertility (Sheldon et al., 2006). The most reliable method of diagnosing this disorder is endometrial cytology to determine the ratio of polymorphonuclear neutrophils (PMNs) to epithelial cells in uterine smears obtained using the cytobrush technique (Kasimanickam et al., 2004; Barlund et al., 2008). Earlier studies on cytologically determined endometritis focused mainly on its impact on postpartum reproductive performance, whereas research into the effect of this disorder during the breeding period has been neglected. Kaufmann et al. (2009) found a correlation between an increased fraction of PMNs near the time of insemination and a significantly reduced first-conception rate. These findings confirmed the significance of cytologically determined endometritis for the success or failure of insemination.

Puerperal endometritis is related to bacterial contamination of the uterus by both pathogenic and non-specific bacteria (McDougall, 2005; Sheldon et al., $2009 a$ ). It is known that until service the majority of cows do not have bacteria in the uterus (Parkinson et al., 2009). However, inflammation may occur without any bacterial infection. The persistence of PMNs in the endometrium in the absence of bacteria is thought to be the primary feature of SE (Sheldon et al., $2009 b$ ).

The influx of PMNs into the uterus is the predominant mechanism of the innate immune response that resolves the infection. The presence of PMNs in the endometrium is part of the inflammatory cascade, which stimulates the secretion of many proinflammatory mediators, including chemokines, cytokines, prostaglandins and leukotrienes (Bondurant, 1999; Wira et al., 2005; Herath et al., 2009b; Sheldon et al., 2009b). However, the local processes in cows with SE are still poorly understood. There were significantly higher levels of $\mathrm{PGF}_{2 \alpha}$ and $\mathrm{PGE}_{2}$ in the uterine fluids of animals with severe endometritis compared with those with mild endometritis (Mateus et al., 2003). In vitro studies reported that the prostaglandin secretory pattern changed during endometritis, with a decreased secretion of $\mathrm{PGF}_{2} \alpha$ being followed by an increased secretion of PGE2 (Herath et al., 2009a). The enzymes prostaglandin-endoperoxide synthase 1 and 2 (PTGS 1 and PTGS 2; previous name cyclooxygenases, $\mathrm{COX}$ ) and prostaglandin $\mathrm{F}_{2 \alpha}$ and $\mathrm{E}_{2}$ synthases (PTGFS and PTGES, respectively) are involved in the pathway for the production of prostaglandins. Three isoforms of PTGES were identified in the bovine endometrium: the cytosolic PTGES (cPTGES) and the microsomal PTGES (mPTGES 1 and 2). However, mPTGES 1 is the main enzyme responsible for PGE production in bovine endometrial cells (Parent and Fortier, 2005). Recently, some studies have investigated the expression of prostaglandin synthase genes in the endometrium of cows with endometritis and in that of healthy animals. Unchanged or diminished mRNA expression of PTGS 2, cPTGES and mPTGES 1 and 2 in cases of SE during the postpartum period was found (Gabler et al., 
2009; Fischer et al., 2010; Johnson et al., 2015). The above-mentioned studies were performed during the postpartum period, whereas comparable studies in repeat-breeding cows have not been carried out until now.

Thus, to understand better the mechanisms underlying repeat breeding syndrome in cows with SE, the aim of this study was to evaluate the mRNA expression of PTGS 2, PTGFS and $m P T G E S 1$ in the endometrium of repeat breeding cows with and without SE.

\section{Materials and methods}

\section{Animals and study design} periments.

The study was approved by the Local Ethics Commission for Animal Ex-

The study was carried out on 20 repeat-breeding Polish Holstein-Friesian cows from a commercial herd with an average milk yield of 7,500 litres. The animals were kept in loose barns and fed grass and maize silage, concentrates, vitamins and mineral supplements. Partial Mixed Ration (PMR) feeding system was used. The cows were four to six years old and were in a similar period post partum (130-150 days in milk).

Repeat-breeding cows were defined as cows with a clinically healthy uterus and three unsuccessful inseminations. Ten cows were repeat-breeding cows with cytologically determined endometritis, and 10 repeat-breeding cows without of SE served as control. SE was diagnosed using the cytobrush method. All cows had a corpus luteum (CL) diagnosed by transrectal palpation and ultrasonography. Biopsy samples of endometrium were obtained and endometrial mRNA expression of the prostaglandin synthases was evaluated using qRT-PCR.

\section{Sample collection and cytological examination}

Endometrial samples from the uterine horn were collected by the cytobrush method as described previously (Barański et al., 2012). The material collected with the cytobrush was transferred to a microscope slide by rolling the brush on the slide for determination of the ratio of PMNs to epithelial cells. The smears were treated with cytologic fixative (Cytofix, Sanco, Poland), allowed to dry for a few minutes, stained using Papanicolaou's method, and examined using a light microscope at $\times 300$ and $\times 600$ magnification. PMNs and epithelial cells among 100 cells were counted by a veterinarian who was blind to the study population. A threshold ratio of 5\% PMNs was used to categorise the cows as having SE. 
Sample collection of endometrial tissue for evaluation of transcripts expression

Endometrial biopsies were obtained using an endometrial biopsy instrument (Hauptner, Solingen, Germany) as described previously (Bonnet et al., 1991). After cleaning the perineum and external genitalia, the biopsy instrument was introduced into the uterus and guided by transrectal palpation. The tissue was immediately placed into a $1.5-\mathrm{ml}$ tube containing a preservative to maintain the integrity of the mRNA (RNA Later, R0901 Sigma), and transported to the laboratory.

\section{RNA extraction}

The biopsy tissues were homogenised in tubes containing Lysing Matrix D beads (116913500, MP Biomedicals) using an MP FastPrep homogeniser. The total RNA was extracted using TRIzol reagent ${ }^{\circledR}$ (T9424, Sigma-Aldrich) according to the manufacturer's instructions. The RNA concentration was determined spectrophotometrically (NANO Drop 2000; OD 260/280).

\section{Real-time $q R T-P C R$}

One microgram of total RNA from each sample was reverse transcribed using a QuantiTest Reverse Transcription kit (205311, Qiagen, Hilden, Germany), following the supplier's protocol. The generated cDNAs were stored at $-20{ }^{\circ} \mathrm{C}$ until use.

The transcription levels of all examined genes were determined as previously described by Piotrowska-Tomala et al. (2012), with modifications. The quantitative reverse transcriptase real-time PCR (qRT-PCR) assays were performed using a 7900HT qRT-PCR system (Applied Biosystems, Warrington, UK), employing the following default thermocycler program for all of the genes: a 10min pre-incubation at $95^{\circ} \mathrm{C}$ was followed by 40 cycles of $15 \mathrm{sec}$ at $95^{\circ} \mathrm{C}$ and $1 \mathrm{~min}$ at $60^{\circ} \mathrm{C}$. A subsequent dissociation step $\left(15 \mathrm{sec}\right.$ at $95^{\circ} \mathrm{C}, 30 \mathrm{sec}$ at $60^{\circ} \mathrm{C}$ and $15 \mathrm{sec}$ at $95^{\circ} \mathrm{C}$ ) ensured the presence of the same product. In each qRT-PCR assay, both the target gene and the housekeeping gene (HKG, GAPDH) were amplified simultaneously on the same plate. All of the reactions were performed in duplicate wells of a 96-well optical reaction plate (Applied Biosystems, catalogue number: 4306737) in a total volume of $20 \mu \mathrm{l}$ containing $9 \mu \mathrm{l}$ of water, forward primer $(160 \mathrm{nM})$ and reverse primer $(160 \mathrm{nM}), 10 \mu \mathrm{l}$ of Power SYBR Green Master Mix (Applied Biosystems, catalogue number: 4367659) and $1 \mu 1$ of 4-fold diluted cDNA (12.5 ng). The primer pairs are shown in Table 1.

\section{Statistical analyses}

All of the data are shown as mean values \pm SEM. The statistical significance of differences in the levels of mRNA expression of all of the evaluated 
mediators between the groups was analysed with a one-tailed nonparametric Mann-Whitney test using Graph PAD Prism version 5.00 software (Graph Pad Software, San Diego, CA, USA). The level of significance was set at $\mathrm{P}<0.05$.

Table 1

Gene transcripts, primer sequences, amplicon length and GenBank accession number

\begin{tabular}{llccc}
\hline Gene & \multicolumn{1}{c}{ Primer sequence } & $\begin{array}{c}\text { Amplicon } \\
\text { length (bp) }\end{array}$ & $\begin{array}{c}\text { GenBank } \\
\text { accession no. }\end{array}$ & Reference \\
\hline $\begin{array}{l}\text { GAPDH } \\
\text { (Bos taurus) }\end{array}$ & $\begin{array}{l}\text { 5'CACCCTCAAGATTGTCAGCA3'/ } \\
\text { 5'GGTCATAAGTCCCTCCACGA3' }\end{array}$ & 103 & BC102589 & $\begin{array}{c}\text { Korzekwa et al. } \\
\text { (2010) }\end{array}$ \\
\hline PTGS 2 & $\begin{array}{l}\text { 5'TGTTTGCATTCTTTGCCCAG3'/ } \\
\text { 5'CATCCTTGAAAAGGCGCAG3' }\end{array}$ & 158 & NM_174445 & $\begin{array}{c}\text { Slonina et al. } \\
\text { (2009) }\end{array}$ \\
\hline mPTGES 1 & $\begin{array}{l}\text { 5'ATCGTGACGGTCCGTCTCTAA3'/ } \\
\text { 5'GCCCTTTGAGATTGTGACAGG3' }\end{array}$ & 158 & NM_1744433 & $\begin{array}{c}\text { Slonina et al. } \\
\text { (2009) }\end{array}$ \\
\hline PTGFS & 5'TGTGGTGCACGTATCACGACA3'/ & 160 & S54973 & $\begin{array}{c}\text { Slonina et al. } \\
\text { (2009) }\end{array}$ \\
\hline 5'AATCACGTTGCCGTCCTCATC3' & & & &
\end{tabular}

\section{Results}

The expressions of PTGS 2, PTGFS and mPTGES 1 mRNAs are presented in Fig. 1.

Significantly higher expression of PTGS 2 mRNA was found in the repeat-breeding cows with SE compared to cows without this disorder $(\mathrm{P}<0.05)$. The difference in the expression of PTGFS and mPTGES 1 mRNAs between cows with $\mathrm{SE}$ and without it was not statistically significant $(\mathrm{P}>0.05)$.

\section{Discussion}

We evaluated the endometrial expression of the genes for some prostaglandin synthases involved in uterine response to endometritis because this information is lacking in repeat breeders. Earlier it was reported that the inflammatory response of the endometrium (cytokines, prostaglandins and leukotrienes) in cytologically determined subclinical endometritis differs from that in clinical endometritis and in a physiological functioning endometrium (Gabler et al., 2009; Fischer et al., 2010; Ghasemi et al., 2012; Barański et al., 2013; Kim et al., 2014; Johnson et al., 2015). However, these results are partially contradictory. The studies cited above were conducted during the first six weeks post partum, whereas there are only few studies about the expression of proinflammatory factors in the endometrium of repeat-breeding cows. Janowski et al. (2013) found a 
significantly higher mRNA expression of TNF $\alpha$ and inducible nitric oxide synthase (iNOS) in repeat-breeding cows with SE, while Kasimanickam et al. (2014) reported greater endometrial mRNA expression of mucin 1, cytokines and Tolllike receptor 4 (TLR-4) in such cows.
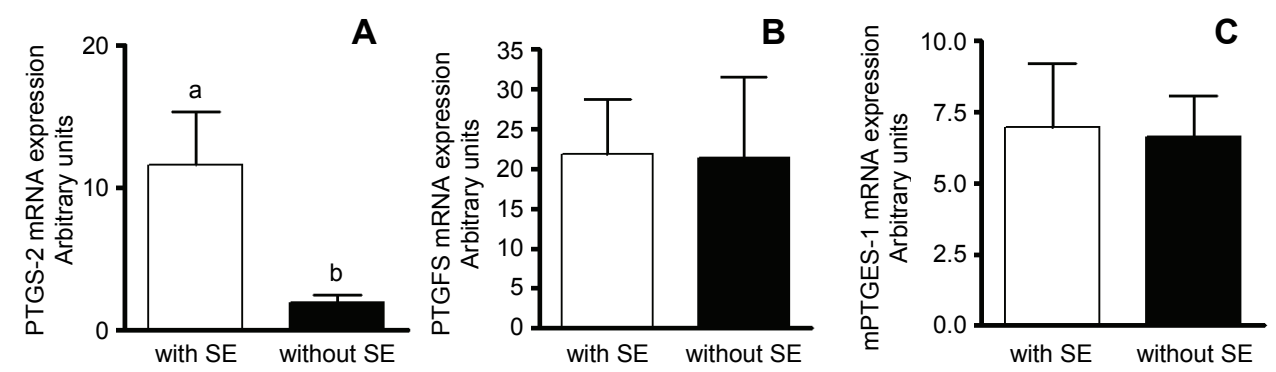

Fig. 1. Expression of PTGS 2 (A), PTGFS (B) and mPTGES 1 (C) mRNAs in the endometrium of cows with and without subclinical endometritis (SE). Different letters above the bars indicate significant differences between the groups $(\mathrm{P}<0.05)$

Prostaglandins play an important role in both endometrial physiological function and uterine pathology (Sheldon et al., 2009b). We found an increased expression of PTGS mRNA in cows with SE compared to cows without it, whereas the expression of PTGFS and mPTGES 1 mRNAs was similar in both groups. These findings are difficult to interpret. Altered prostaglandin secretory patterns have been reported in cases of endometritis of different severity. The endometrial synthesis of prostaglandins was generally upregulated, with an endocrine switch in prostaglandin synthesis from series $\mathrm{F}$ compounds to series $\mathrm{E}$ compounds (Herath et al., 2009a). Our results are only partially consistent with this report because we observed the increased expression of PTGS 2 mRNA, but not PTGFS and mPTGES 1 mRNAs. PTGS 2 is the rate-limiting enzyme for the formation of the common precursor for $\mathrm{PGF}_{2} \alpha$ and $\mathrm{PGE}_{2}$, the synthesis of arachidonic acid from membrane phospholipids (Madore et al., 2003). Increased expression of the gene encoding this enzyme observed in our study suggests the general activation of the prostaglandin pathway during SE in repeat breeders, although without the switch from series F to series E compounds. There are only few reports about how SE modulates the metabolism of prostaglandins, and even these are partially contradictory. Gabler et al. (2009) observed unchanged expression of microsomal prostaglandin $\mathrm{E}_{2}$ synthases (mPTGES 1 and 2) and a 2-fold lower expression of $c P T G E S$ mRNA in SE compared with healthy endometrium during the postpartum period. In contrast, Barański et al. (2013) observed a slight increase of PGE secretion by endometrial cells in subclinical cases of endometritis, depending on the severity of the disorder. Fischer et al. (2010) found a higher expression of PTGS 2 mRNA in the endometrium of cows with SE post partum, although the difference was not statistically significant. Johnson et al. (2015) 
showed a higher expression of $P G E S$ and $P G H S 2$ genes in cows with postpartum endometritis as compared to healthy cows. However, no significant differences were detected between groups with clinical and those with subclinical endometritis.

It is difficult to compare the above-mentioned data with our results due to the different methodological approaches applied in particular studies. These differences include different sampling times post partum, the use of epithelial cells harvested by cytobrush or endometrial tissue obtained by biopsy, and the measurements of mRNAs expression or the secretion of inflammatory mediators.

We evaluated the expression of $m P T G E S 1 \mathrm{mRNA}$, because this isoform is the only prostaglandin $E_{2}$ synthase dynamically and precisely expressed on both gene and protein levels during the oestrous cycle in the bovine endometrium. Increased $m P G E S 1$ expression is clearly associated with increased $\mathrm{PGE}_{2}$ production in bovine endometrial cells in vitro following stimulation with some cytokines (Parent and Fortier, 2005). However, in our study we did not observe such a relationship, because the upregulation of PTGS 2 mRNA was not followed by an increase of $m P G E S 1$ mRNA. The exact contribution of other prostaglandin $\mathrm{E}_{2}$ synthases (i.e. mPTGES 2 and $\mathrm{cPTGES}$ ) to $\mathrm{PGE}_{2}$ production by the bovine endometrium under pathological conditions remains to be elucidated.

In conclusion, our study demonstrated that SE in the repeat-breeding cows is associated with increased endometrial expression of the PTGS 2 gene, which is involved in prostaglandin synthesis.

\section{Acknowledgement}

This study was supported by the Polish MS \& HE No. 544/N-COST/2009/0 research project.

\section{References}

Båge, R., Gustafsson, H., Larsson, B., Forsberg, H. and Rodriguez-Martinez, H. (2002): Repeat breeding in dairy heifers: follicular dynamics and estrous cycle characteristics in relation to sexual hormone patterns. Theriogenology 57, 2257-2269.

Barański, W., Podhalicz-Dzięgielewska, M., Zduńczyk, S. and Janowski, T. (2012): The diagnosis and prevalence of subclinical endometritis in cows evaluated by different cytologic thresholds. Theriogenology 78, 1939-1947.

Barański, W., Łukasik, K., Skarżyński, D., Sztachańska, M., Zduńczyk, S. and Janowski, T. (2013): Secretion of prostaglandins and leukotrienes by endometrial cells in cows with subclinical and clinical endometritis. Theriogenology 80, 766-772.

Barlund, C. S., Carruthers, T. D., Waldner, C. L. and Palmer, C. W. (2008): A comparison of diagnostic techniques for postpartum endometritis in dairy cattle. Theriogenology 69, 714-723.

Bondurant, R. H. (1999): Inflammation in the bovine female reproductive tract. J. Anim. Sci. 77 (Suppl. 2), 101-110. 
Bonnet, B. N., Miller, R. B., Etherington, W. G., Martin, S. W. and Johnson, W. H. (1991): Endometrial biopsy in Holstein-Friesian dairy cows. I. Technique, histological criteria and results. Can. J. Vet. Res. 55, 168-173.

Fischer, C., Drillich, M., Odau, S., Heuwieser, W., Einspanier, R. and Gabler, C. (2010): Selected pro-inflammatory factor transcripts in bovine endometrial epithelial cells are regulated during the oestrous cycle and elevated in case of subclinical or clinical endometritis. Reprod. Fertil. Dev. 22, 818-829.

Gabler, C., Drillich, M., Fischer, C., Holder, C., Heuwieser, W. and Einspanier, R. (2009): Endometrial expression of selected transcripts involved in prostaglandin synthesis in cows with endometritis. Theriogenology 71, 993-1004.

Ghasemi, F., Gonzalez-Cano, P., Griebel, P. J. and Palmer, C. (2012): Proinflammatory cytokine gene expression in endometrial cytobrush samples harvested from cows with and without subclinical endometritis. Theriogenology 78, 1538-1547.

Gustafsson, H. and Emanuelson, U. (2002): Characterization of the repeat breeding syndrome in Swedish dairy cattle. Acta Vet. Scand. 43, 115-125.

Herath, S., Lilly, S. T., Fischer, D. P., Williams, E. J., Dobson, H., Bryant, C. E. and Sheldon, I. M. (2009a): Bacterial lipopolysaccharide induces an endocrine switch from prostaglandin F2 $\alpha$ to prostaglandin E2 in bovine endometrium. Endocrinology 150, 1912-1920.

Herath, S., Lilly, S. T., Santos, N. R., Gilbert, R. O., Goetze, L., Bryant, C. E., White, J. O., Cronin, J. and Sheldon, I. M. (2009b): Expression of genes associated with immunity in the endometrium of cattle with disparate postpartum uterine disease and fertility. Reprod. Biol. Endocrinol. 7, 55-68.

Janowski, T., Barański, W., Łukasik, K., Skarżyński, D., Rudowska, M. and Zduńczyk, S. (2013): Prevalence of subclinical endometritis in repeat breeding cows and mRNA expression of tumor necrosis factor $\alpha$ and inducible nitric oxide synthase in the endometrium of repeat breeding cows with and without subclinical endometritis. Polish J. Vet. Sci. 16, 693-699.

Johnson, H., Torres, C. G., Carvallo, F., Duchens, M. and Peralta, O. A. (2015): Endometrial expression of selected transcripts in postpartum primiparous Holstein cows with clinical and subclinical endometritis. Anim. Reprod. Sci. 156, 34-39.

Kasimanickam, R., Duffield, T. F., Foster, R. A., Gartley, C. J., Leslie, K. E., Walton, J. S. and Johnson, W. H. (2004): Endometrial cytology and ultrasonography for the detection of subclinical endometritis in postpartum dairy cows. Theriogenology 62, 9-23.

Kasimanickam, R., Kasimanickam, M. and Kastelic, J. P. (2014): Mucin 1 and cytokines mRNA in endometrium of dairy cows with postpartum uterine disease or repeat breeding. Theriogenology 81, 952-958.

Kaufmann, T. B., Drillich, M., Tenhagen, B.-A., Forderung, D. and Heuwieser, W. (2009): Prevalence of bovine subclinical endometritis $4 \mathrm{~h}$ after insemination and its effects on first service conception rate. Theriogenology 71, 385-391.

Kim, I.-H., Kang, H.-G., Jeong, J.-K., Hur, T.-Y. and Jung, Y.-H. (2014): Inflammatory cytokine concentrations in uterine flush and serum samples from dairy cows with clinical or subclinical endometritis. Theriogenology 82, 427-432.

Korzekwa, A., Łukasik, K. and Skarżyński, D. J. (2010): Leukotrienes are auto-, paracrine factors in the bovine corpus luteum: an in vitro study. Reprod. Dom. Anim. 45, 1089-1097.

Madore, E., Harvey, N., Parent, J., Chapolelaine, P., Arosh, J. and Fortier, M. (2003): An aldose reductase with $20 \alpha$-hydroxysteroid dehydrogenase activity is most likely enzyme responsible for the production of prostaglandin F2 $\alpha$ in the bovine endometrium. J. Biol. Chem. 278, $11205-11212$

Mateus, L., Lopes da Costa, L., Carvalho, C., Serra, P. and Robalo Silva, J. (2002): Blood and intrauterine leukocyte profile and function in dairy cows that spontaneously recovered from postpartum endometritis. Reprod. Dom. Anim. 37, 31-35. 
Mateus, L., Lopes da Costa, L., Diniz, P. and Zięcik, A. (2003): Relationship between endotoxin and prostaglandin (PGE2 and PGFM) concentrations and ovarian function in dairy cows with puerperal endometritis. Anim. Reprod. Sci. 76, 143-154.

McDougall, S. (2005): Gross abnormalities, bacteriology and histological lesions of uteri of dairy cows failing to conceive or maintain pregnancy. N. Z. Vet. J. 53, 253-256.

Parent, J. and Fortier, M. A. (2005): Expression and contribution of three different isoforms of prostaglandin E synthase in the bovine endometrium. Biol. Reprod. 73, 36-44.

Parkinson, T., Noakes, D. E., Parkinson, T. J. and England, G. C. W. (2009): The repeat breeder syndrome. In: Noakes, D. E., Parkinson, T. J. and England, G. C. W. (eds) Veterinary Reproduction and Obstetrics. 9th edition. Saunders Elsevier, Edinburgh. pp. 463-466.

Piotrowska-Tomala, K. K., Siemieniuch, M. J., Szóstek, A. Z., Korzekwa, A. J., WocławekPotocka, I., Galváo, A. M., Okuda, K. and Skarżyński, D. J. (2012): Lipopolysaccharides, cytokines, and nitric oxide affect secretion of prostaglandins and leukotrienes by bovine mammary gland epithelial cells. Domest. Anim. Endocrinol. 43, 278-288.

Pothmann, H., Prunner, I., Wagner, K., Jaureguiberry, M., de la Sota, R. L., Erber, L., Aurich, C., Ehling-Schulz, M. and Drillich, M. (2015): The prevalence of subclinical endometritis and intrauterine infections in repeat breeder cows. Theriogenology 83, 1249-1253.

Salasel, B., Mokhtari, A. and Taktaz, T. (2010): Prevalence, risk factors for and impact of subclinical endometritis in repeat breeder dairy cows. Theriogenology $\mathbf{7 4}, 1271-1278$.

Sheldon, I. M., Cronin, J., Goetze, L., Donafrio, G. and Schuberth, H. J. (2009a): Defining postpartum uterine disease and the mechanism of infection and immunity in the female reproductive tract in cattle. Biol. Reprod. 81, 1025-1032.

Sheldon, I. M., Lewis, G. S., LeBlanc, S. and Gilbert, R. O. (2006): Defining postpartum uterine disease in cattle. Theriogenology $65,1516-1530$.

Sheldon, I. M., Price, S. B., Cronin, J., Gilbert, R. O. and Gadsby, J. E. (2009b): Mechanisms of infertility associated with clinical and subclinical endometritis in high producing dairy cattle. Reprod. Dom. Anim. 44 (Suppl. 3), 1-9.

Slonina, D., Kowalik, M. K., Subocz, M. and Kotwica, J. (2009): The effect of ovarian steroids on oxytocin-stimulated secretion and synthesis of prostaglandins in bovine myometrial cells. Prostaglandins Other Lipid Mediat. 90, 69-75.

Wira, C. R., Grant-Tschudy, K. S. and Crane-Godreau, M. A. (2005): Epithelial cells in the female reproductive tract: a central role as sentinels of immune protection. Am. J. Reprod. Immunol. 53, 65-76.

Yusuf, M., Nakao, T., Ranasinghe, R. B., Gautam, G., Long, S. T., Yoshida, C., Koike, K. and Hayashi, A. (2010): Reproductive performance of repeat breeders in dairy herds. Theriogenology 73, 1220-1229. 